\title{
Breaking out of the linguistic ghetto? The role of new media in facilitating international research
}

\section{I an M. Johnson}

Professor and Associate Dean, Aberdeen Business School, The Robert Gordon University, Garthdee Road, Aberdeen AB10 7QE, Great Britain

(i.m.johnson@rgu.ac.uk)

\begin{abstract}
The paper reviews some of the challenges faced by researchers whose principal language is not English in accessing appropriate literature. Taking the experience of the Latin American countries as an example, it discusses the challenges implicit in the international ranking of scholarly journals, as well as the barriers imposed by print publishing and by existing indexing services. It considers critically the implications of the emergence of electronic journals, open access publishing, and the development of institutional repositories. Finally, it discusses the issues for researchers that are raised by the new media, including access, sustainability, quality control and the underpinning pedagogic culture.
\end{abstract}

This paper draws on research undertaken in 2004 and 2005 by an international team supported by the European Commission's ALFA Programme. The research project, REVISTAS, investigated the feasibility of digitising professional journals published in Spanish and Portuguese, particularly those published in Latin America, as a means of raising the quality of teaching and research.

\section{I ntroduction}

The transmission of an idea from research to implementation has been widely studied because its contribution to development gives it a wide public significance. Behavioural scientists who have observed this process have noted that it is possible to identify individuals or organisations who may be characterised as 'innovators', whilst those who follow may be described as 'early or late adopters', or even as 'laggards.' These variations in behaviour may, at least in part, be explained by the results of research into the diffusion of innovation, which notes the significance of communication channels in transferring awareness and understanding of innovations (Rogers, 1995).

This paper attempts to explore the role of professional journals as a particular contributor to spreading awareness of research and professional developments, and does so in the context of Latin America. Madkour (1975) identified 3 fundamental obstacles impeding the transformation and modernisation of information services in developing countries: the volume of material being published; its limited geographic dissemination; and linguistic barriers. Whilst accepting that the language barrier remained a largely unsolved problem, Madkour argued that the use of computers and the establishment of international information systems had alleviated the first 2 problems areas. Although his 
judgement may have been premature, this paper will review the opportunity that is now being presented by developments in the applications of new technologies to the communication of information internationally.

Whilst there are many channels through which advances in LIS professional policy and practice could be communicated (J ohnson, et al., 2004), professional journals clearly have a significant role to play in the process of transferring innovative concepts and practices. A key part of that process is the peerreviewed journal. The scholarly journal has developed into the standard means through which ideas and information are communicated within the scholarly community and between the scholarly community and those who seek to apply the results of their research, by providing quality control of research through the development of the editorial peer-review system (Rowland, 2000), and an indexed archive of information (Tomney, 1998). The majority of researchers across all disciplines report that access to refereed journals, whether print or electronic, is essential to their work (Follett, 2002).

Librarianship and Information Sciences (LIS) as an academic discipline in Latin America could be seen to have been insular and lacked cross-fertilization from LIS research practices from other regions. Thirty years ago, Sabor (1977) associated the problems in development of the LIS profession in Latin America profession with the lack of access to international journals and other researchorientated publications. Over the last 20 years, however, concerns have regularly been expressed about the implementation in developing countries generally of development processes in which the objectives, techniques, content and outcomes are derived from the context and values of advanced industrialised countries. Behavioural research has explained that the factors that influence individuals to adopt new ideas include not only the visibility of examples of its successful implementation, as well as their perceptions of both the complexity of introducing and the relative advantages of adopting a new idea, but also their understanding of its compatibility with existing practices. More recently, Sabor (1992) maintained that the development problems in Latin America persisted, but the focus of her concern had shifted to the lack of indigenous journals.

The environment in Latin America for the development of a research infrastructure for LIS is favourable, as the region has not only a sufficient number of academics and practitioners to carry out research but also the regional readership needed to support the publication of a significant number of LIS journals of high scholarly quality. However, Urbizagástegui Alvarado (2004) has suggested that perhaps only about 12 of the LIS journals published in the region have a substantial scholarly content. Indeed, many Latin American journals in the field simply describe what is happening rather than testing and validating it and feeding back the results from that investigation to the wider community.

Studies undertaken at IFLA's behest in 1997, funded by the European Commission's ALFA programme (América Latina Formación Académica) ${ }^{1}$, and in 1998, funded by UNESCO, highlighted the perception of a lack of quality regional

${ }^{1}$ European Commission ALFA programme. [online]: http://europa.eu.int/comm/europeaid/projects/alfa/index_en.htm [Accessed 7 August 2004] 
journals with which to feed, cross-fertilize and sustain budding professional and research practice within the region. Further research, undertaken in 2004 and 2005 with more support from the ALFA programme, investigated the availability of journals published in the region and the feasibility of digitising them to make them more widely available. This paper reviews some of the issues that were identified during that project. It will consider particularly the language barrier that has inhibited a greater proportion of the global LIS profession from engaging with research on an international basis and becoming early adopters of innovations, but will also highlight a number of other, related issues that need to be addressed to enable the region's journals' contribution to development to be overcome.

\section{Research and recognition}

The individual researcher clearly has a key part to play in the development process, and it is therefore important that we understand how they work and how they are motivated. What most researchers seek as the output of their work is that it should make some impact, and that their efforts should achieve some recognition. With recognition comes prestige in their peer group and in society at large, perhaps leading to invitations to participate in professionally significant activities such as journal editing, participating in government committees, and invitations to speak at the major conferences where they can build their network of contacts - the 'invisible college' through which much information about innovations is actually exchanged. It may also lead to promotion in their employment, or the award of public Honours.

In many countries, tenure (a permanent academic post) is generally based on an individual's record of research and publication. The system for promotion - from Lecturer or Assistant Professor through to Senior Lecturer or Associate Professor and ultimately to full professorial rank - is also based largely on an individual's record of research and publication. In some countries, these requirements are specified in explicit quantitative terms.

The highest recognition is generally accorded to papers that appear in the most highly regarded journals - that is those international journals known to have the highest standards for selecting papers offered to them, based on a rigorous system of peer-reviewing. In most cases, that means the journals that are included in the Citation Analyses published by the Institute for Scientific Information in the U.S.A., because the data produced by ISI is that has been used most commonly to assess the productivity of individual and national research efforts and their international standing.

\section{Researchers and publication}

To achieve their aim, the primary motivations of researchers in selecting a journal in which to publish are its readership: the quality of audience and the wide exposure of the results of their work. Researchers in all disciplines, whatever their country of origin, have therefore sought to maximise the exposure of their research by submitting their manuscripts to the wellestablished European and North American journals indexed by ISI. To date, however, the ISI Citation Indexes have only included journals that are published in English. The dominance of the English language has been noted by a number 
of authors, highlighting the esteem attached to those LIS journals included in ISI's Social Science Citation Index, which are long established journals and mainly (but not exclusively) scholarly in their nature and American in origin.

It has been estimated that today two-thirds of the journals indexed by ISI are published in English by Elsevier, Springer, and Taylor and Francis Ingenta, who have been assiduous in ensuring that their journals meet the criteria for indexing by ISI (Thomson Scientific, n.d.). This is not necessarily the result of ethnocentrism. The commercially published indexing and abstracting databases are faced with a deluge of publications. They must exercise strict inclusion policies addressing qualitative, quantitative, and logistic issues, but they have also assumed that the majority of their users have the ability to read English. The addition of any new title to the database of one of these secondary sources represents a considerable financial and technical investment, because there is a commitment to the indexing and abstracting of the yearly runs of the periodical in the future. However, non-inclusion of a journal in major databases is a serious limitation when authors select journals as disseminating venues for their research. The lack of visibility of a journal from the point of view of its inclusion in these major indexing and abstracting sources affects the attraction power it might exert on prospective authors.

The Russian speaking research communities appear to have been well served by abstracting and indexing services (Tomlinson, 1986), but poor coverage of other non-English language journals by widely available abstracting and indexing services has inhibited sharing information with and between the developing regions. It has been suggested that $70 \%$ of all the scientific journals published in Latin America are not included in any indexing service (Ardila, 1999), and little of the Latin American literature in librarianship and information sciences is covered by the relevant English language abstracting and indexing services (Rodriguez, 1987). Papers in the LIS field that are published in the region therefore probably conform to the norm in being cited between $40 \%$ and $60 \%$ less than the world average for papers in the same field (Ardila, 1999).

The problems of accessing foreign language material in librarianship and information science have aroused only occasional concern in the Englishspeaking community. Edwards (1971) examined the limitations of Library and Information Science Abstracts as a source for international and comparative studies. Riley (1992) reported on a wider survey of indexing and abstracting tools held at the University of Tasmania's library to determine the amount of foreign language materials available to researchers working at the University. The research workers themselves were also surveyed in order to ascertain the effects of the foreign language barrier on their ability to access information relevant to their fields of study. The data suggested that there was a considerable barrier which adversely affected information dissemination and that there was a need for the development of library services especially designed to confront this barrier.

In disciplines other than librarianship and information science, however, globalisation has focused some attention on the need to capture the information in journals produced in developing countries. For example, the spread of diseases from developing countries, as a result of increased international travel, has changed the pattern of medical research and related information needs, and 
the emergence of new technologically advanced nations has similarly focused attention on their publications (Sakharusova, 1987).

\section{Research and publication}

Limited geographic dissemination of professional publications remains a problem in many parts of the world, particularly in the less wealthy developing countries. Wise (1994) has noted the limited distribution and short life span of printed African journals in librarianship and information sciences, both within and outside the region. Journal publishing in Latin America has been similarly inhibited. Its problems have been attributed not only by the relatively weak economies in the region, by the poor infrastructure of the book trade (Johnson, 1976; Babini and Smart, 2006), and by the dominance of institutionally supported journals whose editors have no financial incentive to improve distribution.

Wayt-Gibbs (1995) has noted that the attraction power of most indigenous journals is low for elite Latin American authors who 'vote with their feet' and write in English and submit papers for publication elsewhere, giving credence to Garfield (1996) when he claimed that:

"if anything really significant is discovered (in a developing country) it gets into the mainstream journals".

Licea de Arenas et al (2003) in a study of the productivity of Mexican PhD doctoral holders trained abroad found that the majority had selected international publishing outlets in ISI indexed journals. Alternatively they may write in English for journals published in their own countries that are known to have a sufficiently wide circulation outwith the region. Both of these approaches have been supported by specific policies of the research councils in some countries who have given career incentives and financial rewards to academics who publish in journals of high recognition and visibility as defined by their inclusion in major international indexing and abstracting publications. Understandably, Bonilla and Perez Aragon (1999) have questioned the implementation of contradictory policies in some Latin American countries that provide financial support for local journal development whilst at the same time offer incentives to academics to publish abroad.

An explanation for this may be found in the nature of journal publishing in Latin America that has been dominated by journals that are published by universities or with financial support from public institutions, or in the case of LIS by national library associations (Rodriguez Gallardo, 1987) that account for $50 \%$ or more of known professional periodicals. Commercial journal publishing has been inhibited by the relatively weak economies in the region. The editor/publishers of the journals supported by national research councils or through universities depend on the annual budgetary allocation to enable them to sustain regular publication, and have also been affected by financial crises in the region which from time to time have left editors with limited resources (Babini and Smart, 2006), and the editors have not always succeeded in maintaining a regular publication schedule. There may have been other reasons such as a shortage of papers to print, a phenomenon noted by Al-Ansari et al. (2001) amongst the SLIS in the Arabian Gulf States. Moreover, because of their institutional financial support, they may face low expectations of sales revenue (Babini and Smart, 
2006), or even lack any need to recover their costs, and thus have little financial incentive to increase sales improving distribution mechanisms.

These institutional journals are frequently not sold through subscription mechanisms but exchanged in a barter system for journals from other universities or associations. These may eventually enter the collections of some libraries, but not as part of a managed collection development programme and thus libraries' holdings rarely include complete sets (Cano-Reyes, 2003). The editors of the institutionally supported journals have also had no financial incentive to raise standards, and peer review mechanisms in Latin American journals have been lax (Cano, 1992; Meneghini, 1992). Perhaps only about 50 current LIS journals published in the region meet a limited definition of an 'academic' journal and have been published regularly, implying that few are likely to be highly regarded and well known, and thus rarely reach a wide international audience (Urbizagástegui Alvarado, 2004).

\section{Electronic publishing in Latin America}

Conventional print publishing is now universally recognised as inefficient because an increasing number of titles and regular price increases have resulted in fewer purchasers for each title, and the contents of each journal consequently enjoy limited and declining visibility amongst potential readers. As in other parts of the world, several models of electronic publishing are now emerging to serve the needs of the Spanish and Portuguese speaking communities.

Commercial database publishers' interest in the region is growing. Grupo Océano, a Spanish company ${ }^{2}$, EBSCOHost ${ }^{3}$, Thomson Learning ${ }^{4}$, and Dialnet ${ }^{5}$ are all established providers of full-text Spanish and Portuguese journals, and ProQuest ${ }^{6}$ is about to join them. As yet, coverage of librarianship and information science topics in the journals that these include is generally incidental. Moreover, publication of the results of information management research often takes place in the Latin American journals covering the disciplines that provided the context for the research. It is thus scattered and may be difficult to access.

Universities in the region are increasingly active in seeking to increase the visibility of their research, and some have seen the new electronic media as one way to achieve their goal. Some efforts are thus being made by universities (and by professional bodies) to begin to publish their existing journals electronically and to make them available on open access through the World Wide Web. More than 70 Latin American LIS journals have web sites, and at least 35 are published in full-text, whilst 5 others are e-publishing their Tables of Contents, or Abstracts. A number of organisations in Latin America and in Spain are acting as aggregators, hosting links to those electronic journals that are

${ }^{2}$ Grupo Océano [online]: http://www.oceano.com/oceano/oceano.html [Accessed 5 December 2005]

${ }^{3}$ EBSCOHost [online]: http://www.epnet.com/ [Accessed 15 December 2005]

${ }^{4}$ Thomson Learning - Informe [online]: http://www.gale.com/pdf/facts/inform.pdf [Accessed 5 December 2005]

${ }^{5}$ Dialnet [online]: http://www.dialnet.com.mx [Accessed 12 April 2005]

${ }^{6}$ Proquest - Prisma [online]: http://www.il. proquest.com/division/pr/05/20050408.shtml [Accessed 5 December 2005] 
made available on open access. These include RedALyC, Red de Revistas Científicas de América Latina, el Caribe, España y Portugal'7, and REI, Recursos Electrónicos de Información ${ }^{8}$, but their coverage of the available LIS titles varies as a result of different approaches to the selection of titles.

Only a small proportion of printed scholarly periodicals from developing countries has been indexed and abstracted by the major scientific secondary databases, and Latin America is no exception (Whitney, 1992; Cano, 1992; Goncalves da Silva and Silva Fernandez, 1997). However, possibly under gentle pressure from its considerable Spanish customer base (as well, perhaps, as incipient competition from new and more inclusive indexing services such as Google Scholar ${ }^{9}$ and SCOPUS ${ }^{10}$ ), Thomson ISI has recently agreed to begin including journals in Spanish in its Citation Indexes from January 2006. So far only one LIS journal has been selected. Similarly, only one (other) LIS journal has met the quality criteria for inclusion in SciELO ${ }^{11}$, the best known of the open access aggregators in the region (Urbizagástegui Alvarado (2004), which also now includes its own rudimentary citation analysis. The major regional indexing service for LIS, INFOBILA ${ }^{12}$, appears to have covered less than half of the $270+$ LIS journals that have been or are currently being published in the region, and few of the recently developed electronic journals. ${ }^{13}$ In any event, although online and free to use, it appears that it may not be well known to the LIS community in the region or internationally. An impromptu survey of the c. 350 participants of a conference on digital libraries in Argentina in October 2005 suggested that only about 10 people present were familiar with INFOBILA.

\section{Institutional repositories}

In addition to expressing support for open access journal publishing, the Budapest Open Access Initiative ${ }^{14}$ recommended open access self-archiving, where an author deposits in an open website a copy of an un-reviewed paper to seek comment or to draw immediate attention to important research findings, while possibly continuing to publish in conventional journals. Self-archiving in Institutional Repositories is defined by SPARC ${ }^{15}$ as 'a digital collection capturing and preserving the intellectual output of a single or multi-university community.'

\footnotetext{
${ }^{7}$ RedALyC [online]: http://www.redalyc.com/mx [Accessed 3 January 2006]

${ }^{8} \mathrm{REI}$, Recursos Electrónicos de Información [online]:

http://aps. unirioja.es/biblio/recursos?sub=1 [Accessed 3 June 2006]

${ }^{9}$ Google Scholar [online] - http://scholar.google.com/ [Accessed 7 May 2006]

${ }^{10}$ SCOPUS [online] - http://www.scopus.com/scopus/home.url [Accessed 7 May 2006]

${ }^{11}$ SciELO - Scientific Electronic Library Online - is a project of FAPESP - Fundação de Amparo à Pesquisa do Estado de São Paulo in collaboration with BIREME - Centro LatinoAmericano e do Caribe de Informação em Ciências da Saúde, and also supported by CNPq - Conselho Nacional de Desenvolvimento Científico e Tecnológico. [online]: http://www.scielo.br/ [Accessed 7 August 2004]

12 INFOBILA [online]: - http://cuib.laborales.unam.mx [Accessed 7 August, 2004]

${ }^{13}$ A list compiled during the REVISTAS project may be seen at: http://bc.uns.edu.ar/alfa

${ }^{14}$ The Budapest Open Access I nitiative, 2001 [online]:

http: //www. soros.org/openaccess/read.shtml [Accessed November 2003]

${ }^{15}$ SPARC: Scholarly Publishing and Academic Resources Coalition [online]:

http://www.arl.org/sparc/ [Accessed 3 J une 2006]
} 
It is alleged that open access self-archiving is currently generating far more open access articles per year than open-access journal publishing, and may be able to grow much sooner and faster than new e-journals but, as Pinfield (2003) points out, 'the biggest challenge is getting content', i.e. persuading the authors to make their papers available. In Latin America, with its tradition of institutionally supported publishing, this may not be such a problem, but in most cases the development of Institutional Repositories there is at an early stage and it is not possible to certain about whether they will be successful in capturing the majority of their institution's output. Whilst it has many champions who believe that it may become an important complement to journal publishing, it is important to remember that the original application of self-archiving was in the physics community, where the validity of research requires less independent assessment than in more subjective topics such as those covered by much LIS research.

\section{An incomplete solution?}

Making Latin American LIS journals available globally through digital publishing will undoubtedly improve the potential availability of information about developments in the Spanish and Portuguese speaking research communities. It does not, however, seem to provide a complete solution to the problems.

Whilst some Latin American researchers may be reluctant to publish in their own language, other researchers in their own country may not read English well enough to understand the results of their work, if they publish internationally. It is clear that information professionals in Latin America are not immune from linguistic handicaps to accessing information about international developments in LIS, a field in which the predominant language of the prestigious, internationally available journals tends to be English. Discussions with educators in the region in 1997 indicated that while many institutions had a number of staff who spoke fluent English, and many more who read it because it is the main language of communication in the discipline area, the ability of students to speak or read English varied from institution to institution (Johnson, 1998).

Linguistic handicaps may prevent some researchers publishing in the international journals, but if they publish papers in Spanish or Portuguese, that may inhibit many others from accessing information in them. Babini and Smart (2006) have commented on the fact that, for many potential readers in the English-speaking research community, the need to read in Spanish or Portuguese:

"... not only prevents access and use of the published content ..., but also even discovery of the journals within the Latin American indexes, which - naturally - are also in Spanish and Portuguese."

Historically, most of the conventional English language journal publishers have rejected the concept of preparing and publishing multi-lingual abstracts of papers in their journals as an unnecessary cost. IFLA's Journal is a notable exception, conditioned by the nature of the organisation rather than a publisher's policy. Some publishers of journals in other languages have, however, adopted the practice of publishing abstracts in English. The journal, Hungarian Library Abstracts has published English summaries of all the significant papers originating in that country. The Polish Library Association's web site recently 
began to include Ebib, with abstracts in English of the significant papers published in that country. ${ }^{16}$ In a global society, with widening opportunities for higher education probably leading to a lower proportion of graduates fluent in English, is it now time for a reconsideration of the need for a more comprehensive approach to the provision of multilingual abstracts?

Is that the highest priority for the journals publishers in Latin America? Should it be? Libraries and publishers in Latin America and Spain face a number of other challenges if they are to offer effective access to the region's research for the international research community:

- developing digital collections that provide a more comprehensive coverage of the information outputs of the region;

- providing easy cost-effective access to the relevant databases, electronic journals and other information resources that exist in digital formats;

- resolving the issues of quality control in the journals;

- developing a profession that is evidence based.

Commercial publishers and not-for profit intermediaries are increasingly expected to provide online the full text of older articles that had previously been accessible only to a printed journal's subscribers or through document delivery services. Currently, there are few journals pre-dating 1997 available online, mainly as a result of the efforts of their editors to do the necessary processing. The aim of the SciELO project is to encourage the participating publishers to ensure that all the issues of their journals are available online from 1997, when SciELO was established, but earlier material is not expected to be digitised until the initial aim has been achieved. SciELO itself includes only about $2 \%$ of the 15,000 titles represented in Latindex ${ }^{17}$, the main directory of journals in the region. OCLC and SCOPUS have recently incorporated the indexes that the Dirección General de Bibliotecas in the Universidad Nacional Autónoma de México has compiled for the last 28 years, but few of those 400 journals are available online in full-text. Moreover, the evidence points to the existence of incomplete runs of printed journals in libraries (Cano-Reyes, 2003), and it is anticipated that any efforts to digitise older journals in Latin America will face a similar challenge to that encountered in planning for an extension of the LAPTOC database ${ }^{18}$, where difficulties were encountered in finding complete collections to index (Williams, 2003). This also suggests that digitising collections retrospectively may prove to be costly.

The budgetary constraints on Latin American University Libraries, and the generally lower level of Internet penetration and PC ownership and use in the region seem likely to depress the subscriptions that the commercial publishers could demand. For universities outwith Latin America and I beria, where the number of potential users of Spanish and Portuguese language journals in all disciplines will be small, the subscription charges may be prohibitive for many institutions. These factors may inhibit such rapid development as has been achieved by the publishers of English language journals who have had a much

${ }^{16}$ EBIB - Elektroniczna Biblioteka [online]: http://www.ebib.info [Accessed 3 June 2006]

${ }^{17}$ Latindex [online]: http://www. latindex.unam. mx/ [Accessed 3 June, 2006]

${ }^{18}$ LAPTOC: Latin American Periodicals Tables of Contents [online] -

http: //lanic. utexas. edu/larrp/laptoc.html [Accessed 7 May 2006] 
larger and generally more affluent market to underpin the significant investment required.

The technology lends itself to creating electronic collections that offer the user such benefits as cross-file searching, browsing, saved search histories, and Table of Contents alerts by email, are increasingly expected as standard features of ejournal services. For example, to meet the growing demands of users for links to cited papers, CrossRef ${ }^{19}$ was developed to enable publishers to provide reference linking between electronic journals, using a Digital Object Identifier system to provide permanent online access to the full text of identified documents, uninhibited by content ownership. Inevitably, the cost of all these features, and the associated manual work, must be factored into the development of both electronic journals and Institutional Repositories, and that must raise concerns about their effectiveness and future sustainability in many developing countries. The problem is compounded by the fact that many National Libraries may not have a preservation policy that extends to electronic media produced in their country - or the resources to implement one.

Just because journals begin to appear in digital formats does not mean that the issues of quality control will be addressed. If researchers within the region and internationally are to regard reading the journals published in Latin America as worthwhile, they will need to be re-assured about their quality. The SciELO service does require peer-reviewing as one of its criteria for inclusion, and also includes a citation analysis, albeit currently only at the level of the journals rather than individual authors or papers. Whilst the citation analysis may develop, SciELO covers only about $2 \%$ of the journals published in Latin America. Although comparisons between ISI's Citation Indexes and Google Scholar are already beginning to appear, and comparisons with SCOPUS will no doubt appear soon, the debate about the extent to which their indexing is more comprehensive and whether their approach to 'open peer-reviewing' is a more relevant measure of a paper's or a journal's significance will be unresolved for some time. It will be some time before the impact on the aspirations of Latin American authors and journal editors of the potential for inclusion of Spanish language journals in ISI's Citation Indexes can be fully evaluated, but the pressure on editors and institutional managements from academic researchers to publish in journals that are included by ISI cannot be under-estimated.

The state of development of research and scholarly publishing activities in LIS must be understood within the context of higher education in Latin America as a whole. Cultural and pedagogical practices as well as a political lack of awareness of the value of information as a resource have acted against the development of environments that are information rich for teaching and learning activities as a whole (Sanchez Diaz and Vega Valdez 2003). Lau (2001) has described the development of a user education programme at a Mexican University, presenting a picture of a pedagogical environment in which memorization, note-taking based on attendance to lectures, and a focused demand for textbooks are indicative of a lack of research skills. Following one of the few reported studies of the use of LIS journals within the region, Cano-Reyes (2003) stressed the need for lecturers to make more use of journals within their teaching and learning practices. If pedagogical practices do not develop students' skills in

${ }^{19}$ CrossRef was viewed on the Web in November 2003 at URL - http: www.crossref.org 
finding information, critically evaluating it, and synthesising the results, how can a research community evolve and develop a strong and supportive publishing culture?

(c) The author, June 2006

\section{AUTHOR}

Ian Johnson is Associate Dean of the Aberdeen Business School at the Robert Gordon University. As Head of the University's former School of Librarianship and Information Studies, he led the development of a wide range of courses and research in library and information sciences, publishing and communication studies. He has been Chairman of British, European and International groups concerned with education and training for Librarianship and Information Studies, and of the Professional Board of the International Federation of Library Associations and Institutions (IFLA). He is currently joint editor of Libri: international journal of libraries and information services, and a member of the Editorial Board of Education for Information.

The author gratefully acknowledges the efforts of Sara Lansdale and Virginia Cano that have contributed to the development of this paper.

\section{REFERENCES}

AL-ANSARI, H., REHMAN, S., and YUSUF, N. (2001). Faculty in the Library Schools of the GCC member nations: an evaluation. Libri, 51 (3), September, 173-181

ARDILA, R. (1999). Scientific publishing in Latin America: the case of journals in the behavioural and social sciences. in: Revistas científicas en América Latina - Scientific Journals in Latin America; edited by A.M. CETTO and O. ALONSO. Paris: International Council of Scientific Unions; Mexico: UNAM, CONACYT, and Fondo de Cultura Económica. p. 209

BABINI, D., and SMART, P. (2006). Using digital libraries to provide online access to social science journals in Latin America. Learned Publishing, 19 (2), 107-113

BONI LLA , M., and PEREZ ARAGON, M. (1999). Revistas Mexicanas de Investigación Científica y Tecnológica. Ínterciencia 24(2), 102-106.

CANO, V. (1992). Bibliographic control and international visibility of Latin American periodical publications. in: Indicators for developing countries; edited by R. Arvanitis and J. Gaillard. Paris: ORSTOM. pp. 511-526.

CANO-REYES, V. (2003). Las revistas académicas en el aprendizaje del estudiante de biblioteconomía. in: XXXIV Jornadas Mexicanas de Biblioteconomía. Puerto Vallarta, Jalisco, México. [online]: http://www.ambac.org.mx/publicaciones/memorias/34 jornadas.pdf [Accessed 15 J anuary, 2006]

EDWARDS, T. (1971). The foreign language barrier to international studies in library and information science: problems in LISA. in: An evaluation of the sources for 
comparative librarianship in the United Kingdom: proceedings of the one day conference held in London on 14 November, 1970. Library Association, International and Comparative Librarianship Group/College of Librarianship Wales, pp. 8-14.

FOLLETT, B. (2002). Perspectives on the RSLG Final Report: introduction. New Review of Academic Librarianship, 8, 87-91

GARFIELD, E. (1996). The significant scientific literature appears in a small core of journals. The Scientist, 10 (17), 2 September, 13.

GONCALVES DA SILVA, L., and SILVA FERNANDES, R. (1997). La cobertura de las revistas Latinoamericanas por los Servicios de Indización: el caso de las revistas brasileñas [Coverage of Latin American journals by the indexing services, with reference to Brazilian journals]. Paper presented at the Second International Workshop on Scientific Publishing in Latin America, Guadalajara, Mexico, November 27-30. [Unpublished?]

JOHNSON, I.M. (1998). RELACION - Red Europea y LAtinamericana en Clencias de la informaclON: Report to European Commission, Directorate General IB - External Relations for the period 1997 - 1998 on the Network supported by $\alpha$ lfa: Amerique Latine Formation Academique, Exchange Programme between Universities of the European Union and of Latin America. Aberdeen: The Robert Gordon University. (Unpublished typescript)

JOHNSON, I.M., WILLIAMS, D.A., WAVELL, C., and BAXTER, G. (2004). Impact evaluation, professional practice, and policymaking. New Library World, 105 (1196/1197), January, 33-46

JOHNSON, P.T. (1976). A brief overview of the book trade in Spanish speaking Latin America in: Seminar on the Acquisition of Latin American Library Materials (19, 1974, Austin, Texas). Final report and working papers. Amherst, Mass.: SALALM Secretariat pp. 55-59

LAU, J. (2001). Faculty-Librarian collaboration: a Mexican Experience. Reference Services Review, 29 (2), 95-105.

MADKOUR, M.A. (1975). Linguistic impediments on information transfer for and from the Arab states: towards an automated solution. in: Proceedings of the symposium on scientific and engineering secondary information transfer for the developing countries: sponsored by ICSU Abstracting Board and the World Federation of Engineering Organisations Committee on Engineering Information in association with UNISIST; held at the Bibliothèque Royale Albert Ier Brussels, 23-24 June 1975. Paris: International Council of Scientific Unions Abstracting Board, pp. 47-59

MENEGHINI, R. (1992). Brazilian production in Biochemistry: the question of international vs domestic. Scientometrics, 23 (1), 21-30

PINFIELD, S. (2003). Open Archives and UK Institutions. D-Lib Magazine, 9(3), March. [online]: http://www.d; ib/march03/pinfield/03pinfield.html [Accessed November 2003]

RILEY, C. (1992). The foreign language barrier in information transfer at the University of Tasmania. Aslib Proceedings, 44 (10) October, 331-40

RODRIGUEZ GALLARDO, A. (1987). Las publicaciones periódicas de bibliotecología en los países en desarrollo. [Librarianship periodicals in developing countries.] Investigación Bibliotecológica: archivinomia, bibliotecología e información, 1 (2), January-J une, 3-14 
ROGERS, E.M. (1995). Diffusion of innovation. $4^{\text {th }}$ ed. New York, U.S.A.: Free Press.

ROWLAND, J.F. (2000). Who will buy my bells and whistles?: the true needs of users of electronic journals. Serials, 13 (2), July, 73-77

SABOR, J.E. (1977). [Review of] Irebi, Índices De Revistas De Bibliotecología. UNESCO Bulletin for Libraries, 31(1), January-February, 40, 41, 60).

SABOR J.E. (1992). The issue of librarianship in Argentina. Third World Libraries, 3 (1), Fall, 40-46.

SAKHARUSOVA, M.B. (1987). Comparative analysis of the role of Japanese journals in abstracting publications. [Sopostavitel'nyi analiz otrazheniya yaponskikh zhurnalov $v$ referativnykh izdaniyakh.] Nauchnye- i Tekhnicheskie Biblioteki SSSR, (12), 17-20

SANCHEZ DIAZ, M. and VEGA VALDEZ, J. (2003). Consideraciones teoricas y estado actual de las politicas de Informacion en América Latina. ACIMED 11(3). [online]: http://eprints.rclis.org/archive/00001773/01/consideraciones.pdf [Accessed 15 J anuary, 2006]

THOMSON SCIENTIFIC (n.d.) [ISI] Journal Selection Process [online] http://scientific.thomson.com/free/essays/selectionofmaterial/journalselection/ [Accessed 7 May 2006]

TOMLINSON, D.M. (1986). LISA: anatomy of an abstracting service. Indexer, 15 (2) October, 83-86

TOMNEY, H., and BURTON, P.F. (1998). Electronic journals: a study of usage and attitudes among academics. J ournal of Information Science, 24 (6), 419-29

URBIZAGÁSTEGUI ALVARADO, R. (2004). Latin American journals in library and information science [ Las revistas de bibliotecología y ciencias de la información en América Latina. in: World Library and I nformation Congress: 70th IFLA General Conference and Council, 22-27 August, Buenos Aires, Argentina. [online]: http://www.ifla.org/IV/ifla70/prog04.htm [Accessed 29 August, 2004]

WAYT GIBBS, W. (1995). Lost Science in the Third World. Scientific American, 273 (2) August, 92-99.

WHITNEY, G. (1992). Access to Third World science in international scientific and technical bibliographic databases. in: Indicators for developing countries; edited by R. Arvanitis and J. Gaillard. Paris: ORSTOM. pp. 391-411.

WI LLIAMS, G. (2003). International resource sharing: the ARL Latin Americanist Research Resources Project. in: Models of Cooperation in U.S., Latin American and Caribbean Libraries: the first IFLA/SEFLIN international summit on library cooperation in the Americas; edited by B.E. Massis. Munich: K. G. Saur. pp.52-55

WISE, M. (1994). Survival under adverse conditions: proceedings of the African Library Service J ournals Workshop (IFLA), Bayero University, Kano, Nigeria, 29-30 J anuary 1992. The Hague, Netherlands: IFLA. IFLA Professional Reports, 38. 